\title{
Dampak Politik Identitas Pada Pilpres 2019: Perspektif Populisme The Impact of Identity Politics On President Election 2019: Populism Perspective
}

\author{
Aryojati Ardipandanto
}

Pusat Penelitian, Badan Keahlian DPR RI

email: aryojati.ardipandanto@gmail.com

\begin{tabular}{l} 
Riwayat Artikel \\
\hline Diterima: 12 Agustus 2019 \\
Direvisi: 10 Maret 2020 \\
Disetujui: 21 April 2020 \\
doi: 10.22212 /jp.v11i1.1582
\end{tabular}

\begin{abstract}
Some people said that populism through identity politics played a vital role in the 2019 Presidential Elections campaign rallies, and it was considered to be a threat to the unity of the nation. The kind of populism at play in the 2019 Presidential Elections was populism that was based on identity politics, mainly on religion. The disparity between supporters of both candidates was set created in such particular condition that it created an image of opposing groups of religiously pious supporters against those who practice religion loosely. From this point of view, this paper was established based on identification of problems in the danger of populism practiced in the 2019 Presidential Elections. This paper employs analytical descriptive literature method. It concludes that the danger of populism in the 2019 Presidential Elections was basically caused by separation of groups of people based on religious sentiments, a practice that was often supported by both candidates and allowed some people to take advantage of the situation to create disunity of Indonesia as a nation. In the future, both the Government and the Legislators have to involve community leaders in educating the public about good political and democratic practices, so as to ensure better democracy in Indonesia from time to time, based on the foundation of Pancasila-led Democracy. Keywords: Populism; Politics of Identity; Presidential Elections 2019.
\end{abstract}




\section{Latar Belakang}

Pemilu Serentak 2019 telah selesai dilaksanakan. Pada Pemilu tersebut, Pemilihan Presiden (Pilpres) dilaksanakan bersamaan dengan Pemilu Legislatif. Berbagai kalangan menilai bahwa Pilpres lebih banyak menjadi isu yang menarik perhatian sebagian besar masyarakat Indonesia daripada Pemilu Legislatif. Proses kampanye Pilpres juga mengalami dinamika dan eskalasi yang kuat dimana terjadi saling menyerang kelemahan masing-masing Calon Presiden oleh para pendukungnya masing-masing. ${ }^{1}$ Hasil Pilpres 2019 pun sempat mengalami kontroversi, dimana pihak Pasangan Calon (Paslon) Nomor 2, yaitu Calon Presiden (Capres) Prabowo Subianto dan Calon Wakil Presiden (Cawapres) Sandiaga Uno mengajukan gugatan ke Mahkamah Konstitusi (MK) terkait keberatan atas hasil perhitungan suara Pilpres yang memenangkan Paslon Nomor 1, yaitu Capres Joko Widodo (Petahana) dan Cawapres K.H. Ma'ruf Amin. ${ }^{2}$

Beberapa kalangan menyayangkan proses pelaksanaan Pemilihan Umum (Pemilu) Serentak 2019, khususnya pada momen Pemilihan Presiden (Pilpres). Alasannya adalah karena dari berbagai kondisi situasi politik yang terjadi pada masa kampanye Pilpres 2019, termasuk pada masa pra kampanye, terlihat bahwa gejala yang terjadi adalah menguatnya eksploitasi identitas sebagai propaganda politik, atau politisasi Suku, Agama, Ras, Antar

1 Dian Basuki. "Pamor Pileg Tenggelam oleh Pilpres," Indonesiana, 27 April 2019, diakses 3 Juli 2019, https://www.indonesiana.id/read/130137/pamorpileg-tenggelam-oleh-pilpres.

2 Zunita Putri dan Dwi Andayani. "MK Tolak Gugatan Pilpres Prabowo-Sandiaga," detiknews, 27 Juni 2019, diakses 6 September 2019, https://news. detik.com/berita/d-4603147/mk-tolak-gugatanpilpres-prabowo-sandiaga.
Golongan (SARA). Gejala selanjutnya adalah meningkatnya ujaran kebencian hate speech yang memenuhi ruang publik selama beberapa tahun sebelum dan pada saat pelaksanaan Pilpres 2019, ditambah lagi dengan sikap elit politik yang tidak memberi contoh yang baik, malahan menunjukkan sikap yang anti demokrasi, cenderung hanya siap menang dan tidak siap kalah. Hal ini besar kemungkinan akan menjadi faktor yang membuat indeks demokrasi Indonesia akan semakin menurun. Ini dipandang akan menjadi catatan buruk bagi proses demokrasi di Indonesia. Bila seandainya nanti indeks demokrasi Indonesia semakin menurun, maka demokratisasi di Indonesia akan menjadi kurang baik di mata dunia internasional. $^{3}$

Pada Pemilihan Umum 2019, politik identitas anti-establishment dinilai kembali menguat ketika beredarnya narasi-narasi yang membawa konsep populisme. Uniknya, identitas anti-establishment ini dikaitkaitkan oleh identitas agama yang selalu dipakai politisi populis untuk menarasikan bahwa pemerintah memarginalkan kelompok muslim. Misalnya Gerakan "2019 Ganti Presiden", "partai setan vs partai Allah", people power, tidak percaya kepada lembaga-lembaga mapan (KPU dan $\mathrm{MK}$ ) maupun lembaga independen (quick count, dll). Jika digunakan terus-menerus, politik identitas anti-establishment agama yang memperhatikan semangat golongan dan partai ketimbang semangat persatuan menyebabkan polarisasi yang meluas di kalangan masyarakat ataupun para elite-

3 Rizki Akbar Putra. "Pengamat Pasca Pemilu: Pendidikan Demokrasi Penting untuk Membangun Persatuan; Wawancara dengan Pengamat Politik, Direktur Eksekutif Indonesian Public Institute (IPI) oleh Jurnalis Deutsche Welle, Rizki Akbar Putra," 28 Juni 2019, diakses 27 Juli 2019, https://www. dw.com/id/pengamat-pasca-pemilu-pendidikandemokrasi-penting-untuk-membangun-persatuan. 
elite politik. Para politisi seharusnya lebih berfokus kepada narasi politik sehat yang mempersatukan dan mendamaikan para pendukungnya dengan mengedepankan rasionalitas bukan emosionalitas ataupun kepentingan kelompok agama tertentu. Bahkan, elite-elite politik seharusnya lebih mengedepankan isu-isu nasional yang membangun secara progresif dan substantif terhadap narasi-narasi politiknya. Masyarakat Indonesia harus mulai mampu berpikir rasional dan kritis, terutama dengan isu-isu politik dan agama yang cenderung dimanipulasi oleh elite-elite politik. Preferensi politik masyarakat harus lebih didasarkan pada keberanian berpikir sesuai nalar rasionalnya di tengah cengkeraman elite-elite dan otoritas politik keagamaan. Keberanian dalam berpikir rasional serta menjadi individu yang kritis membuat terciptanya masyarakat yang terbuka serta toleran dalam menghadapi isu-isu sosialpolitik. ${ }^{4}$

Sebelum pelaksanaan Pilpres 2019, beberapa kalangan telah "meramalkan" bahwa populisme yang berbasis politik identitas akan terjadisecara kuat pada Pilpres 2019. Setelah Jokowi memilih Ma'ruf Amin sebagai cawapres, Peter Mumford, analis di perusahaan riset Amerika Serikat Eurasia Group, memperingatkan bahwa agama akan mulai memainkan peran yang lebih besar dalam politik Indonesia. Terlepas dari semboyan nasional Indonesia "Bhinneka Tunggal Ika," yang berarti "berbeda-beda tetapi tetap satu jua," sentimen mayoritas Muslim terhadap kelompok minoritas, yaitu etnis Tionghoa yang dianggap mengendalikan sebagian besar ekonomi bangsa telah menyebabkan pertumpahan

4 Harun Ar-rasyid, "Populisme, Politik Identitas dan Pemilu 2019," detiknews, 11 Mei 2019, diakses 2 Juli 2019, https://news.detik.com/kolom/d-4545249/ populisme-politik-identitas-dan-pemilu-2019. darah di masa lalu. Jika komunitas Muslim konservatif tumbuh lebih kuat sebagai hasil dari Pemilu Presiden 2019, nilainilai demokrasi Indonesia akan kembali dipertaruhkan. ${ }^{5}$

Setelah pelaksanaan Pilpres 2019 pun, beberapa kalangan menilai politik identitas sangat berperan dalam kampanye Pilpres. Bahkan, dikatakan bahwa data dan fakta dinilai tidak banyak meningkatkan suara elektoral. Politik identitas dengan strategi post truth ternyata lebih efektif dalam Pilpres 2019. Politik identitas menjadi winning template yang biasanya "dikawin-kawinkan" dengan strategi post truth. Strategi tersebut tampak lebih "bertuah" secara elektoral jika dibandingkan dengan data dan fakta. Politik identitas telah terbukti melahirkan polarisasi yang tajam. Exit poll Indikator Politik terhadap 2.975 responden yang baru mencoblos pada 17 April 2019 memberikan gambaran bagaimana terbelahnya masyarakat Indonesia. Indikator menemukan bahwa kelompok muslim tradisionalis dan non muslim cenderung memilih Joko Widodo-Ma'ruf Amin, sedangkan muslim modernis cenderung memilih Prabowo Subianto-Sandiaga Uno. Pemilih nonmuslim yang memilih Jokowi-Ma'ruf mencapai 97 persen, naik 15 persen jika dibandingkan 2014. Demikian juga dengan pemilih yang dekat dengan NU memilih Jokowi-Ma'ruf. Pada Pilpres 2019, 56 persen warga Nahdiyin mengaku memilih Jokowi-Ma'ruf, naik 12 persen dibandingkan pemilu lima tahun 2014. Sebaliknya, Prabowo-Sandiaga menang telak di kalangan warga Muhammadiyah, Persis, dan ormas-ormas modernis lainnya. Karena politik identitas, pemilih sudah

5 Surahmat, "Review Toru Takahashi (Nikkei Asian Review)," mata-mata politik, 24 Juli 2019, diakses 31 Juli 2019, https://www.matamatapolitik.com/ analisis-pidato-kemenangan-jokowi-bagaimanadiksi-ungkap-pesan-politiknya. 
memutuskan pilihan jauh sebelum masa kampanye terbuka dimulai. ${ }^{6}$

Ada juga pandangan yang melihat aspek politik identitas dalam Pilpres 2019 yang dikaitkan dengan daerah yang berbasis ke-Islaman yang relatif dipandang kuat. Salah satunya adalah di Provinsi Sumatera Barat, dimana perolehan suara Capres Nomor 1 Jokowi kalah dari Paslon Nomor 2 (Prabowo-Sandi). Dikatakan bahwa gencarnya sosialisasi dan kebijakan pemerintah Jokowi dalam membangun Sumbar ternyata tidak mampu mengangkat perolehan suara Jokowi. Sebabnya adalah prestasi pemerintah Jokowi tak mampu melunturkan politik identitas dan sentimen negatif masyarakat Sumatera Barat terhadap dirinya dan Partai Demokrasi Indonesia Perjuangan (PDI-P). Jokowi dianggap "tidak ramah" dengan umat Islam, yang mana hal itu berdampak juga ke PDI-P sebagai partai pengusung utama Paslon Nomor 1. Apa yang dibangun dan prestasi dari pemerintahan Jokowi tidak ada artinya karena sentimen keagamaan dan argumen politik identitas yang kuat. Dengan kata lain, Jokowi dianggap masyarakat Sumbar sebagai tokoh capres yang berjarak dengan umat Islam. ${ }^{7}$

Sebaliknya, masyarakat Sumbar memberikan apresiasi kepada capres nomor urut 02, Prabowo Subianto beserta partai pengusungnya, Gerindra, Partai

6 Christoforus Ristianto, "Politik Identitas Dianggap Sebagai Winning Template di Pilpres 2019”, kompas. com, 29 Mei 2019, diakses 29 Mei 2019, https:// nasional.kompas.com/read/2019/05/29/20001181/ politik-identitas-dianggap-sebagai-winningtemplate-di-pilpres-2019.

7 Christoforus Ristianto, "Kalah Telak di Sumbar, Prestasi Jokowi Tak Mampu Luluhkan Politik Identitas", kompas.com, 15 Mei 2019, diakses 31 Juli 2019, https://nasional.kompas.com/ $\mathrm{read} / 2019 / 05 / 13 / 12132811 /$ kalah-telak-di-sumbarprestasi-jokowi-tak-mampu-luluhkan-politikidentitas.
Amanat Nasional (PAN), Partai Keadilan Sejahtera (PKS), dan Partai Demokrat yang dianggap memperjuangkan aspirasi umat Islam. Isu-isu berbasis politik identitas dan agama semakin mengurangi elektoral Jokowi di Sumbar. Masyarakat Sumbar dinilai memiliki irisan keislaman yang relatif berbeda dengan pendukung umat Islam-nya Jokowi. Masyarakat Sumbar memiliki preferensi agama yang berbeda dengan preferensi agama yang mendukung Jokowi. Jokowi dan PDI-P dinilai kurang "bersahabat" dengan umat Islam. Hal itu terlihat dari isu-isu tentang kriminalisasi ulama, penangkapan aktivis Islam, dan sebagainya. Meskipun di koalisi pendukung Jokowi terdapat tokoh-tokoh umat Islam, hal itu tidak mampu mencairkan kuatnya politik identitas dan sentimen negatif terhadap masyarakat Sumbar terhadap Jokowi. Hal ini dikarenakan isu-isu berbasiskan keagamaan sudah terbangun dalam masyarakat selama masa kampanye Pemilu 2019. Isu-isu berbasiskan keagamaan tersebut telah mengalahkan prestasi pemerintah Jokowi. Apalagi, potret masyarakat di Sumbar masih sosiologis dan emosional dalam menjadikan agama sebagai instrumen utama preferensi politik. ${ }^{8}$

Melihat fenomena-fenomena di atas, mengamati proses pelaksanaan Pilpres 2019 dari sudut pandang populisme yang didasari strategi politik identitas menjadi menarik untuk dikaji. Terlebih lagi, penting untuk dikaji bagaimana bahaya populisme dengan strategi politik identitas tersebut terhadap demokrasi di Indonesia. Kajian ini perlu dicermati karena Indonesia adalah Negara yang penduduknya sangat majemuk, terdiri dari berbagai suku, agama dan ras, yang terikat dengan Dasar Negara Pancasila dan

8 Christoforus Ristianto, "Kalah Telak di Sumbar, Prestasi Jokowi Tak Mampu Luluhkan Politik Identitas." 
semboyan Bhinneka Tunggal Ika. Apalagi, berbagai kalangan menilai bahwa populisme yang menggunakan politik identitas sangat rawan bagi keutuhan persatuan dan kesatuan Bangsa Indonesia, khususnya dalam mengupayakan kehidupan demokrasi yang semakin baik dari waktu ke waktu. Selain itu, kajian mengenai populisme dalam Pilpres 2019 penting untuk dilakukan sebagai bahan masukan mengenai fenomena yang terjadi pada Pilpres 2019 bagi Komisi II DPR RI dalam rangka melakukan rencana revisi UU Pemilu pada tahun 2020. ${ }^{9}$

\section{Rumusan Masalah}

Populisme dengan menggunakan politik identitas sebenarnya merupakan bagian dari strategi politik untuk memenangkan persaingan politik, khususnya pemilu. Namun, berbagai kalangan di masyarakat menilai bahwa populisme yang menggunakan politik identitas sudah terlalu jauh dipraktekkan dalam persaingan politik, khususnya dalam Pilpres 2019, yang mana hal tersebut dinilai dapat mengancam persatuan dan kesatuan bangsa yang berdasarkan Pancasila. Atas dasar itu, kajian ini menganalisa bahaya populisme dalam penyelenggaraan Pilpres 2019. Dengan demikian, perumusan masalah dalam tulisan ini terkait pertanyaan apa bahaya populisme dalam penyelenggaraan Pilpres 2019.

\section{Tujuan Penulisan}

Tulisan ini bertujuan memberikan gambaran bagaimana populisme dipraktekkan dalam penyelenggaraan Pilpres 2019, yaitu dalam konteks berkampanye guna memenangkan persaingan politik, yang

9 Mochamad Zhacky, "Komisi II DPR Prioritaskan Revisi UU Pemilu di 2020," detiknews, 14 November 2019, diakses 2 Januari 2020, https://news.detik. com/berita/d-4784680/komisi-ii-dpr-prioritaskanrevisi-uu-pemilu-di-2020. dilakukan peserta Pilpres 2019. Tujuan berikutnya, berdasarkan gambaran tersebut, adalah memberikan masukan bagaimana populisme yang berbahaya dapat dihindari pada pelaksanaan Pilpres pada masa selanjutnya. Hal ini dapat menjadi bahan masukan bagi Komisi II DPR RI yang merencanakan merevisi UU tentang Pemilu pada tahun 2020.

\section{Kerangka Pemikiran}

\section{Politik Identitas}

Politik identitas sendiri merupakan konsep baru dalam kajian ilmu politik. Politik identitas adalah nama lain dari biopolitik dan politik perbedaan. Biopolitik mendasarkan diri pada perbedaan-perbedaan yang timbul dari perbedaan tubuh. Dalam filsafat, sebenarnya wacana ini sudah lama muncul, namun penerapannya dalam kajian ilmu politik mengemuka setelah disimposiumkan pada suatu pertemuan internasional Asosiasi Ilmuan Politik Internasional di Wina pada $1994 .{ }^{10}$

Pertemuan tersebut menghasilkan konsepsi tentang dasar-dasar praktek politik identitas dan menjadikannya sebagai kajian dalam bidang ilmu politik. Agnes Haller mengambil definisi politik identitas sebagai konsep dan gerakan politik yang fokus perhatiannya adalah perbedaan (difference) sebagai suatu kategori politik yang utama. Setelah kegagalan narasi besar (grand narative), ide perbedaan telah menjanjikan suatu kebebasan (freedom), toleransi dan kebebasaan bermain (free play), meskipun kemudian ancaman baru muncul. Politik perbedaan menjadi suatu nama baru dari politik identitas; rasisme (race thinking), biofeminimisme dan perselisihan etnis menduduki tempat yang terlarang oleh

10 Agnes Heller and Sonja Puntscher Riekmann, Biopolitics: The Politics of The Body, Race and Nature (Brookfield: Avebury, 1996), ix. 
gagasan besar lama. Berbagai bentuk baru intoleransi, praktek-praktek kekerasan pun muncul. ${ }^{11}$

Dalam situasi keterserakan identitas dan entitas-entitas perbedaan, politik perbedaan dan entitas-entitas perbedaan, politik perbedaan sangat subur dalam situasi negara atau masyarakat yang multikultural dan multietnis. Dalam kerangka ini, hubungan interaktif antar kelompok perbedaan, terutama kelompok etnis yang berbeda-beda harus menjalin suatu kerangka etis, dalam hal ini adalah sikap toleran. Toleransi politik hanya mungkin dalam suasana politik negara yang demokratis. Oleh karena toleransi politik (political tolerance) sangat dipengaruhi oleh sistem, struktur, dan atmosfer politik yang berlaku. John Sullivan dalam Hefner (2007) yang menganalisis konsep dan penerapan toleransi politik di tiga negara yang berbeda: Amerika Serikat,Selandia Baru, dan Israel, menemukan kadar intensitas toleransi yang berbeda-beda. Hal tersebut dipengaruhi oleh faktorfaktor antara lain tingkat kemakmuran ekonomi, struktur dan sistem politik, faktor psikologi politik. Konsep politik identitas relevan untuk diterapkan, paling tidak diwacanakan mengingat peta politik masa depan, yang berkembang ke arah politik yang beragam, lebih melihat kembali pada tataran humanitas dan etik. Geoff Mulgan dalam Hefner (2007), seorang ilmuwan politik, mengemukakan bahwa peranperang etis dan moral harus dikedepankan. Oleh karena seiring runtuhnya narasi besar, ideologi-ideologi besar, partai-partai politik berkurang perannya. Moralitas pun akan lebih dibutuhkan untuk mengatasi gejolakgejolak politik dan menumbuhkan perilaku politik yang etis dan bermoral. Sejalan dengan Mulgan, Walter Lippmann dalam

11 Heller and Riekmann, Biopolitic, ix.
Hefner (2007) dalam filsafat publiknya mendorong para politikus demokrasi untuk menjunjung tinggi moralitas berpolitik. Hal ini dikarenakan dalam negara-negara demokratis sekalipun penyakit dari terbukanya kebebasan akan senantiasa muncul, sehingga perlu adanya suatu tatanan etika dan moralitas demokrasi. ${ }^{12}$

Klaus Von Beyme dalam Hefner (2007) menganalisis karakter gerakan identitas dalam beberapa tahap perkembangannya, mulai dari tahap pramodern sampai dengan postmodern. Perpecahan fundamental, kelompok-kelompok kesukuan dan kebangsaan memunculkan gerkan sosial politik yang menyeluruh. Dalam hal ini mobilisasi secara ideologis diprakarsai oleh para pemimpin. Tujuannya adalah perampasan dan perebutan kekuasaan dari suatu penguasa ke penguasa yang baru. Pada tahap modern, gerakan tersebut muncul dengan adanya pendekatan kondisional, keterpecahan membutuhkan sumber-sumber untuk dimobilisasi. Terjadi keseimbangan mobilisasi dari atas dan partisipasi dari bawah, peran pemimpin tidak lagi dominan dan tujuan akhirnya adalah pembagian kekuasaan. Kemudian pada perkembangan pos modern, munculnya gerakangerakan itu berasal dari dinamikanya sendiri, protes muncul atas berbagai macam kesempatan individual, tidak ada satu kelompok atau pecahan yang dominan. Pola aksi dan kegiatannya berdasarkan kesadaran diri yang bersifat otonomi sebagai tujuan finalnya. ${ }^{13}$

Kemunculan politik etnis diawali dengan tumbuhnya kesadaran yang mengidentikkan mereka kedalam suatu golongan atau kelompok etnis tertentu. Kesadaran ini kemudian memunculkan

12 Robert W. Hefner, Politik Multikulturalisme: Menggugat Realitas Kebangsaan (Yogyakarta: Impulse, 2007), 46.

13 Hefner, Politik Multikulturalisme, 47. 
solidaritas kekelompokan dan kebangsaan. Politik etnis mengacu pada politik "kelompok etnis" dan "minoritas kecil", sementara penfsiran kelompok etnis bisa mencakup bangsa etnis (ethnic nation). Pada wacana politik kontemporer nuansanya lebih sempit. Dalam konteks ini, biasanya kelompok etnis atau minoritas etnis tidak memiliki teritori tertentu. Tujuan mereka pun berbeda dengan nasionalis klasik, mereka tidak menghendaki "determinasi diri kebangsaan" dalam suatu wilayah bangsa (negara). Akan tetapi, lebih pada penerimaan proteksi dan kemajuan bagi kelompok, khususnya bagi individu-individu dalam kelompok itu, dalam suatu negara yang telah ada. ${ }^{14}$

Selanjutnya, Fukuyama menyatakan bahwa isu-isu identitas telah mendominasi politik dalam beberapa tahun terakhir. Banyak pihak mungkin berpandangan bahwa semua diskusi tentang identitas dan politik identitas politik sebagai strategi pengalihan, karena isu etnis dan agama, misalnya, sering hanya digunakan untuk menyamarkan isu kepentingan kelas. Pemberian identifikasi bahwa "rakyat" melawan musuh-musuh yang tidak dikenal dan sering tidak disebutkan namanya adalah kesempatan yang menguntungkan untuk tidak membahas tentang pelanggaran HAM, korupsi yang sistematis, dan oligarki. Disebutkan lebih jauh lagi bahwa secara intinya, populisme berhubungan dengan polarisasi, dramatisasi, dan moralisasi politik. Dapat dikatakan bahwa populisme selalu merupakan sub-tipe dari politik identitas. Sebagai "ideologi yang tipis" dia bergabung dengan fragmen gagasan tambahan dari tradisi-tradisi seperti liberalisme, konservatisme, dan sosialisme dengan

14 James G. Kellas, The Politics of Nationalism and Ethnicity: Edisi II (New York: ST Martin's Press, 1988), 119. tujuan membangun atau membangun kembali masyarakat yang homogen secara budaya dan etnis. Pada waktu yang sama, kelompok elit sering tidak terkecualikan karena alasan etnis, bukan karena alasan moral. ${ }^{15}$

\section{Populisme}

Ada berbagai macam definisi populisme, walaupun tidak menghasilkan kesepakatan bersama dalam mendefinisikannya secara seragam. Mudde (2014) memberikan penjelasan mengenai populisme sebagai posisi politik yang menempatkan masyarakat kebanyakan atau rakyat biasa berhadapan (vis-a-vis) secara antagonistik dengan elit politik yang dianggap korup, kemudian politik merupakan satu bentuk ekspresi keinginan secara umum masyarakat kebanyakan. ${ }^{16} \quad$ Populisme cenderung menarik perhatian 'rakyat' untuk melawan struktur kekuasaaan yang sudah mapan serta pemikiran dan nilai-nilai dominan dalam masyarakat, yang mana didalamnya termasuk ajakan untuk melakukan revolusi atas nama rakyat melawan para elit. ${ }^{17}$

Beberapa pemikiran lain melihat populisme sebagai ekspresi politik yang memiliki beberapa elemen, antara lain: antikemapanan (dalam arti mewakili ekspresi kelompok yang merasa termajinalkan), kemudian adanya otoritas kepemimpinan yang menonjol lewat karisma atau figur personal atau

15 Francis Fukuyama, Against Identity Politics (New York: Foreign Affairs, September/Oktober 1-25, 2018), 14.

16 Cas Mudde, The Populist Zeitgeist: Government and Opposition (Cambridge: Cambridge University Press, 2014), 114.

17 Alejandro Pelfini, Ed. Boike Rehbein, Global and National Political Elites in South America: Limited Transnationalization Processes and The Persistence of Inequality in Globalization and Inequality Inemerging Societies (Basingstoke: Palgrave-MacMillan, 2015), 201. 
melalui pesan-pesan yang tendensius dan apokaliptik, lalu adanya perasaan in-group yang kuat, dan menunjukkan adanya posisi antagonistik antara dua pihak, yang mana garis pembatasnya bisa berdasarkan status ekonomi, penduduk asli dan migran, atau yang bersifat SARA. Abercombrie dalam Hefner (2007) mengatakan bahwa populisme diartikan sebagai "suatu bentuk khas retorika politik yang menganggap keutamaan dan keabsahan politik terletak pada rakyat, memandang kelompok elit dominan sebagai pihak yang korup, dan sasaran-sasaran politik akan dicapai paling ideal adalah melalui hubungan langsung antara pemerintah dan rakyat, tanpa perantara lembaga-lembaga politik yang ada". ${ }^{18}$

Canovan menyatakan bahwa populis mengklaim adanya legitimasi yang mereka miliki bahwa mereka mewakili rakyat serta mewakili kedaulatan demokratik, tidak sekedar mewakili kepentingan kelas tertentu. Para akademisi pada akhirnya bersepakatbahwapemahaman mengenaiapa itu populisme menjadi sebuah konsep yang dipertarungkan (contested concept), karena tidak ada konsensus bersama mengenai pemahaman mengenai populisme, walaupun dari semua definisi yang ada sebenarnya ada persamaan yang bisa ditarik. Berdasarkan berbagai pemahaman mengenai populisme, Canovan membagi populisme menjadi tiga jenis. Pertama, populisme wong cilik, yang berorientasi pada petani, borjuis kecil, kaum buruh, dan selalu antagonistik terhadap elit politik dan kaum borjuasi besar yang dianggap selalu punya skenario untuk menindas rakyat kebanyakan atau wong cilik. Populisme jenis pertama ini tidak sepakat dengan ide-ide kemajuan yang merupakan produk kapitalisme yang sangat ditentangnya. Populisme kedua adalah

18 Hefner. Politik Multikulturalisme, 126. populisme otoriter, yang mengharapkan munculnya para pemimpin karismatik dari sebuah proses demokratis. Pemimpin yang lahir dari populisme jenis ini bisa mengarah pada otoritarianisme dan totaliter jika lama berkuasa. Jenis populisme ketiga adalah populisme revolusioner, yang merupakan perwujudan pemikiran kolektif menolak segala macam bentuk elitisme dan ideide tentang kemajuan, serta menggalang ide-ide pembaruan yang revolusioner. Tatanan dan institusi politik dinilai tidak lebih dari perwujudan dominasi elit atas rakyat sehingga harus dirubah dan direbut melalui dukungan penuh pada pemimpin revolusioner yang dianggap mewakili kepentingan rakyat banyak. ${ }^{19}$

Selanjutnya, definisi populisme yang lebih luas diartikan sebagai serangkaian strategi yang digunakan oleh politisi yang menjanjikan lebih dari apa yang dapat mereka realisasikan, atau yang mencoba meningkatkan popularitas dengan memperlihatkan kedekatannya dengan rakyat jelata dan berbicara dengan bahasa mereka. Dapat pula dikatakan bahwa populisme dapat dipahami sebagai gaya komunikasi tertentu dengan pemilih, atau perpanjangan kepemimpinan personalis oleh politisi karismatik. Bahkan, dalam sebagian besar definisi, aspek anti-elit atau kritik terhadap kemapanan dimasukkan. Salah satu pendekatan yang biasa dipakai dalam mengamati populisme adalah yang dinamakan ideational approach (pendekatan ideasional). Mudde (2004) mendefinisikan populisme sebagai "ideologi yang menganggap masyarakat terbagi secara absolut dalam dua kelompok homogen dan antagonis, 'rakyat yang murni' melawan 'elit yang korup', dan berpendapat bahwa

19 Margaret Canovan, Ed. Yves Me'ny and Yves Surel, Taking Politics to The People: Populism as The Ideology of Democracy; Democracies and The Populist Challenge (Basingstoke: Palgrave, 2002), 71-74. 
seharusnya politik adalah ungkapan volonté générale (kehendak umum) rakyat". ${ }^{20}$ Demikian juga, Muller (2015) memahami populisme sebagai “... imajinasi politik yang bersifat moralistis tertentu, cara memahami dunia politik yang menempatkan rakyat yang murni secara moral dan sepenuhnya bersatu dalam posisi berlawanan dengan kelompok minoritas, khususnya kelompok elit, yang ditempatkan di luar rakyat yang otentik". ${ }^{21}$

Populisme terkait dengan konsep rakyat yang homogen (karena sebetulnya tidak ada masyarakat yang ada sekarang yang benarbenar homogen) selalu berhubungan dengan peminggiran terhadap pihak yang lain. Pihak yang lain itu dapat berupa kelompok keagamaan atau etnis, kriminal, migran, pengguna narkoba, homoseksual, dll. Para populis biasanya tidak mendefinisikan istilah mereka dengan jelas. Laclau (2005) menyatakan konsep populisme yang dia istilahkan sebagai "penanda kosong". ${ }^{22}$ Melengkapi hal itu, Moffit (2016) menyebutkan bahwa "Rakyat" digambarkan sebagai berbudi luhur, homogen, dan sebagai korban dari kelompok elit yang merasa tidak terikat dengan mereka. Dengan bantuan manipulasi, berita palsu dan media yang dikendalikan, rakyat di ditipu agar mempercayai bahwa rezim yang berkuasa saat ini tidak sah. Moffit juga menyatakan bahwa seorang politisi yang membagikan semua jenis manfaat dan menjanjikan dunia dan akhirat demi memenangkan pemilu, yang berpura-pura mengetahui apa yang dipikirkan dan dirasakan oleh "rakyat jelata" dan terus menerus menyerang elit yang korup - belum tentu populis. Prinsipnya

20 Mudde, The Populist Zeitgeist, 541-543.

21 Jan-Werner Muller, Parsing populism. Who is and who is not a populist these days? (New York: Juncture, 2015), 80-83.

22 Ernesto Laclau, On Populist Reason (London: Verso, 2005), 76. adalah bahwa dalam antagonisme yang dibangun harus ada kesenjangan antara yang "baik" dan "jahat". Elit yang "jahat" akan membawa seluruh negeri ke "jurang yang dalam" apabila para populis tidak mengambil alih dan menyelamatkan "rakyat". Moffit menegaskan bahwa populisme selalu antielitis. Pada kenyataannya, bisa saja sang populis berasal dari kelompok elit ini, tetapi sekarang dia berupaya untuk dekat dengan rakyat dan menampilkan dirinya sebagai orang luar dari elit itu. ${ }^{23}$

\section{Keterkaitan Populisme dengan Politik Identitas}

Populisme berkaitan erat dengan politik identitas. Keterkaitan populisme dan politik identitas salah satunya tergambar dalam penelitian yang berjudul Political Identities: The Missing Link in The Study of Populism (Melendez \& Cristobal, 2017). Argumen akademik (theoretical review) Melendez \& Cristobal dalam penelitian ini ialah populisme dapat berkembang hanya ketika politik identitas antiestablishment ada. Hal itu berarti bahwa populisme yang mengklaim bahwa konsep rakyat merupakan kehendak mutlak, dijadikan "senjata andalan" yang terkemas dalam bentuk narasi-narasi identitas antiestablishment para politisi populis yang ditujukan kepada lawan politiknya. Mereka mengklaim bahwa para elite yang berada di pemerintahan yang mapan bukanlah orangorang yang mendukung rakyat. ${ }^{24}$

Melengkapi penjelasan tersebut, Schedler (1996) mengklasifikasikan corak politisi populis yang narasinya irasionalitas.

23 Benjamin Moffit, The Global Rise of Populism: Performance, Political Style and Representation (Redwood City: Stanford University Press, 2016), 242.

24 Melendez \& Cristobal, Political Identities: The Missing Link in The Study of Populism (New York: Juncture, 2017), 157. 
Pertama, irasionalitas instrumental (cognitive-instrumental irrationality). Banyak politisi populis menuduh musuh mereka tidak kompeten dalam memerintah negara. Bahkan, politisi populis antiestablishment mengatakan bahwa elit-elit yang berada di pemerintahan merupakan orang-orang buruk dari ahli yang buruk. Elit-elit pemerintah menurut mereka tidak hanya bodoh dalam mengelola negara, tetapi juga minim akal sehat dalam berpolitik. Misalnya, menggambarkan pejabat publik sebagai amatir, tidak kompeten, tidak masuk akal, berpandangan pendek, tidak realistis, kacau, bingung, tergesa-gesa, kontradiktif, dan sebagainya. Kedua, irasionalitas normatif (normative irrationality). Politisi populis anti-establishment mempertanyakan konsistensi pemerintah dalam membuat kebijakan publik. Mereka berpolemik melawan pengkhianatan, korupsi, ketidakadilan, dan ancaman bangsa asing. Menurut retorika para pemimpin populis, pejabat publik menghabiskan sebagian besar waktu kerja mereka dalam "menjual" rakyat kepada bangsa-bangsa asing. Selain itu, para populis menganggap bahwa satusatunya hal yang pejabat publik dan eliteelite pemerintah minati adalah untuk memajukan kepentingan egois untuk diri mereka sendiri. Ketiga, irasionalitas ekspresif (expressive irrationality). Para populis antiestablishment biasanya mengedepankan pandangan sinis dan melihat kesenjangan dalam masyarakat. Para populis menganggap pejabat publik hanyalah aktor yang katakatanya tidak berharga. Mereka secara rutin berbohong atas janji-janji politik yang diberikan kepada rakyat. Lebih dari itu, para politisi populis memandang bahwa retorika politik yang di suarakan oleh pejabatpejabat publik merupakan pepesan kosong. Oleh karenanya, pejabat publik dianggap sebagai dua wajah yang menggunakan standar ganda dalam sebuah drama teater politik saja. ${ }^{25}$

Selanjutnya, khusus di Indonesia, dalam artikel yang diterbitkan oleh Tony Blair Institute berjudul Populists in Power Around the World, Kyle dan Gultchin (1997) mengatakan bahwa corak populisme di Indonesia merupakan populisme yang tergolong sebagai cultural populism. Kyle dan Gultchin menjabarkan bahwa populisme ini mengklaim adanya pemisahan antara konteks orang asli (pribumi) dengan orang asing. Dalam hal ini, identitas orang pribumi digunakan sebagai narasi untuk membangun pandangan bahwa orang-orang asing inilah musuh orang asli. Meskipun konteksnya merupakan sosio-budaya, para populis biasanya tidak terpaku terhadap menarasikan politik cultural populism sebagai isu-isu terhadap budaya saja. Mereka bisa saja menarasikan hal-hal yang terkait dengan ekonomi sebagai pendorong untuk efektivitas dalam membuat narasi budaya tersebut. Dengan demikian, mereka membentuk sebuah antar-keterkaitan (dialektika) terhadap isu-isu tersebut yakni dengan mengklasifikasikan para elite-elite rezim pemerintah sebagai musuh bersama. ${ }^{26}$

Konsep anti-establishment tersebut biasanya menuntut pemerintahan yang mapan untuk menyelesaikan hal-hal ekonomi seperti penghapusan praktik korupsi, menurunkan harga bahan pokok, dan mengembalikan pengaruh orang asli dalam praktek perekonomian di negara. Dengan demikian, para aktor-aktor populis ini berhasil memanfaatkan identitas antiestablishment sebagai kekuatan politik. Secara tidak langsung, mereka membentuk

25 Andreas Schedler, "Anti Political Establishment Parties" Journal Party Politics Diego Volume 2 Chile: Diego Portales University (July 1996): 291-312.

26 Jordan Kyle dan Limor Gultchin, Populists in Power Around the World (London: Tony Blair Institute, 1997), 85. 
sebuah hubungan seperti yang Schedler (1996) katakan sebagai A Triangular Symbolic Space dengan klasifikasi tiga aktor utama yakni pemerintah, rakyat, dan para populis itu sendiri. ${ }^{27}$ Pola ini menggambarkan bagaimana hubungan pemerintah dan masyarakat dipandang sebagai representasi orang-orang jahat dan licik, sedangkan hubungan masyarakat dan aktor populis anti-establishment hidup dalam harmoni yang dianggap sebagai pahlawan. Skenario ini juga membentuk anggapan bahwa mereka yang "di atas" tidak termasuk dalam komunitas dari mereka yang ada "di bawah". Dengan kata lain narasi ini membentuk sebuah pandangan identitas: mereka bukan hanya musuh, tetapi juga representasi orang-orang asing (the others). Hal tersebut mendukung pemahaman bahwasanya para politisi populis sering membingkai dan menggabungkan dua atau tiga tipe populisme tersebut, tergantung dengan kondisi sosial-politik yang terjadi di masyarakat. Demikian juga, bagaimana kondisi pemilih yang termotivasi oleh banyaknya masalah yang dinarasikan dalam sosial-politik seperti, melihat pemimpin populis semata-mata melalui "kacamata" ekonomi, budaya, atau identitas antiestablishment. ${ }^{28}$

\section{Populisme dan Demokrasi}

Sebagaimana disinggung sebelumnya, populisme selalu anti-elitis dan antipluralis. Muller (2015) menyebutkan bahwa kalau ada satu saja "rakyat yang asli, yang sebenarnya" dan bukan pluralitas kelompok dengan identitas berbeda dalam satu masyarakat, implikasinya adalah hanya ada satu kebenaran. Hanya kelompok populis yang mewakili "rakyat yang sebenarnya", mereka tidak sekedar berbicara atas nama

27 Schedler, Anti Political Establishment Parties, 146.

28 Schedler, Anti Political Establishment Parties, 147. rakyat, tetapi juga memandang diri mereka sendiri sebagai orang-orang "terpilih" yang mewujudkan kehendak rakyat dan mengetahui apa yang dipikirkan oleh "orang biasa". Dengan demikian, mereka adalah "anti-pluralis berprinsip" yang "tidak dapat menerima apa pun seperti oposisi yang sah". Karenanya, partai-partai populis hanya mendefinisikan diri mereka sebagai gerakan, karena mereka berpura-pura mewakili lebih banyak daripada hanya sebagian rakyat. Mereka lebih suka menggunakan nama seperti Alternative für Deutschland (AFD, Alternatif bagi Jerman), Podemos (Kita bisa), Forza Italia (Maju Italy), MoVimento 5 Stelle (Gerakan Lima Bintang), Thai Rak Thai (Rakyat Thailand mencintai orang Thailand), dll. yang menunjukkan oposisi mendasar terhadap partai-partai politik tradisional atau mapan. ${ }^{29}$

Konsep tentang antagonisme esensialis dan tentang elit berkuasa yang "jahat" berkaitan dengan keyakinan bahwa seluruh negara berada dalam situasi krisis yang mendasar dan secara mendesak harus diambil alih oleh kelompok populis. Jika pihak penguasa tidak bermoral, sangat logis mengasumsikan konspirasi media arus utama, aparat negara, elit ekonomi, dan lainlain. Menurut pemikiran ini, media yang dikendalikan oleh elit menyebarluaskan berita palsu, dan lembaga penelitian dan lembaga survei memalsukan hasil-hasil penelitian dan survei mereka. Apabila kelompok populis kalah dalam pemilihan, mereka biasanya mempertanyakan legitimasi mereka dan menafsirkan hasil pemilihan sebagai hasil manipulasi dan kecurangan. Ini berarti, pemilihan bukan dipandang sebagai mekanisme untuk menawarkan pilihan yang berbeda bagi para pemilih atau untuk akhirnya menemukan apa yang sebenarnya dikehendaki oleh para pemilih, melainkan

29 Muller, Parsing populism, 85-86. 
sebagai sarana bagi kelompok populis untuk membuktikan bahwa hanya pihak populis dan hanya mereka saja yang benar. ${ }^{30}$

Lebihjauhlagi, menurutUrbinati (2019), populisme terdiri dari penghancuran prinsipprinsip demokrasi, mayoritas rakyat, dengan cara yang ditujukan untuk mengelu-elukan sebagian rakyat melalui pemimpinnya, yang menggunakan dukungan penonton untuk memurnikan pemilihan karakter prosedural dan formalistik mereka. Pemilihan, dengan demikian, sangat ambivalen bagi kelompok populis. Di Indonesia, selama bermingguminggu Prabowo Subianto mengklaim kemenangan setelah pelaksanaan pemilihan presiden pada bulan April 2019. Dia melakukan itu bahkan ketika dihadapkan dengan hasil perhitungan cepat yang sangat andal yang dilakukan oleh lembaga survei serius yang memperlihatkan bahwa dia telah kalah dengan selisih yang cukup besar (berbeda dengan dugaan "perhitungan sebenarnya" yang dilakukan oleh timnya sendiri). Di Turki, kira-kira pada waktu yang sama, Recep Tayyip Erdogan tidak bersedia menerima kekalahan di dalam pemilihan di Istanbul. Begitu kelompok populis memenangkan pemilihan, mereka cenderung memperkuat daya cengkeraman mereka. Akibatnya adalah penguraian sistem pengawasan dan perimbangan. ${ }^{31}$

Selanjutnya, perlu ditekankan bahwa populisme bertumpu pada hubungan antara pemimpin dan pengikutnya. Stavrakakis dkk (2016) menyatakan bahwa sering kali, rakyat dianggap pasif dan dimanipulasi oleh para populis, tetapi bangkitnya kaum populis baru-baru ini sebagian besar dipicu oleh penggunaan yang cerdas media sosial seperti YouTube, Twitter, Instagram dan Whatsapp. Oleh karena itu, terlalu

30 Muller, Parsing populism, 87.

31 Nadia Urbinati, Political Theory of Populism. Annual Review of Political Science, Vol. 22 (New York: Forthcoming, 2019), 20. mudah untuk memahami rakyat hanya sekedar sebagai penonton. Populisme tidak semata-mata muncul dari atas dengan seorang pemimpin karismatik membangun dukungan melalui rayuan dan dengan memanipulasi kerumunan yang antusias. Setidaknya yang juga penting adalah sisi permintaan populisme. Gerakan sosial kadang-kadang terorganisasi dengan baik, kadangkadang sebagian besar hadir dengan tidak dikoordinasi di ruang siber, menciptakan pemimpin mereka sendiri. Dengan demikian, populisme adalah sebuah interaksi yang rumit. ${ }^{32}$

\section{Populisme yang dilakukan Paslon Nomor 2 (Prabowo-Sandi)}

Beberapa kalangan beranggapan bahwa pihak Paslon Nomor 2 dominan melakukan politik identitas atau populisme untuk memainkan sentimen SARA di masyarakat, terutama pada unsur agama. Namun sebenarnya, Paslon Nomor 1 juga pada akhirnya memainkan politik identitas atau populisme untuk mengimbangi seranganserangan politik yang bersifat sentimen keagamaan dari Paslon Nomor 2. Namun demikian, latar belakang pemakaian politik identitas dan populisme antara kedua Paslon tampaknya berbeda. Pada awal masa kampanye Pilpres 2019, Paslon Nomor 1 kurang tampak menunjukkan arah menuju strategi politik dengan mengedepankan politik identitas. Hal ini dibuktikan dengan kampanye-kampanye Paslon Nomor 1 yang lebih bersifat menunjukkan prestasiprestasi Capres Jokowi selama menjadi Presiden, terutama dalam hal pembangunan

32 Stavrakakis, Yannis, Kioupkiolis, Alexandros, Katsambekis, Giorgos, Nikisianis, Nikos, dan Siomos, Thomas, Contemporary Left-wing Populism in Latin America: Leadership, Horizontalism, and Postdemocracy in Chávez's Venezuela: Latin American Politics and Society (Caracas: Latin American, 2016), 64. 
infrastruktur. Sebaliknya, Paslon Nomor 2 sudah melakukan itu sejak awal-awal masa kampanye, dengan mengedepankan sisi-sisi kelemahan sosok Capres Jokowi dalam hal latar belakangnya yang diberitakan oleh pihak Paslon Nomor 2 adalah kurang Islami, bahkan cenderung berafiliasi pada kekuatan asing yang ingin menjajah ekonomi Indonesia, dan juga tudingan bahwa Capres Jokowi berlatar belakang keluarga PKI, atau sebagai sosok yang menganut paham komunisme.

Lebih dikedepankannya strategi populisme oleh Paslon Nomor 2 tampaknya dikarenakan untuk menyerang Capres Jokowi dari segi kinerja adalah kurang cukup kuat untuk mengarahkan opini masyarakat untuk tidak bersimpati lagi kepada Capres Jokowi. Memang, kritik terhadap kebijakankebijakan ekonomi pada masa pemerintahan Presiden Jokowi yang banyak menimbulkan kontroversi di berbagai kalangan masyarakat cukup membuat pihak Paslon Nomor 1 beserta jajaran Tim Pemenangannya, serta masyarakat pendukungnya menjadi kewalahan, yaitu dalam melakukan counter attack atas serangan politik Paslon Nomor 2 tersebut. Sebabnya adalah karena memang berbagai kalangan menyatakan bahwa kebijakan-kebijakan ekonomi Presiden Jokowi kurang berpihak pada pengusaha pada sektor-sektor usaha tertentu, terutama yang berkaitan dengan pajak ekspor-impor. Isu-isu ketidakstabilan harga-harga bahan pokok juga dimainkan menjadi serangan politik yang cukup mengemuka oleh Paslon Nomor 2 terhadap Capres Jokowi.

Selanjutnya, populisme yang jelas tampak pada pihak Paslon Nomor 2 adalah adanya ajakan untuk melakukan suatu gerakan mengganti Presiden pada tahun 2019. Isu ini bahkan sampai ditampilkan secara terang-terangan dalam Debat Calon Gubernur/Wakil Gubernur Provinsi Jawa
Barat pada tahun 2018, dimana salah satu Pasangan Calon dalam pidato penutup Debat Calon Gubernur/Wakil Gubernur Provinsi Jawa Barat membentangkan spanduk yang bertuliskan "2019 Ganti Presiden”, yang merupakan jargon kuat dari pihak pendukung Paslon Nomor 2 dalam Pilpres 2019. Pola-pola ini merupakan ciri khas yang kuat dari suatu populisme politik yang memenuhi unsur ajakan untuk melakukan suatu "revolusi" dengan didasari doktrinasi dan kampanye yang mengedepankan isu bahwa kekuasaan atau pemerintahan yang ada saat itu adalah kekuasaan atau pemerintahan yang tidak baik, kekuasaan atau pemerintahan yang bukan suatu good governance, dan kekuasaan atau pemerintahan yang dijalankan oleh Presiden Jokowi pada masa pemerintahannya sejak tahun 2014 adalah pemerintahan yang bukan diinginkan oleh masyarakat Indonesia.

Pihak Paslon Nomor 2 akhirnya mencermati bahwa nilai yang dominan pada sebagian besar masyarakat Indonesia adalah nilai-nilai yang berkaitan dengan agama, khususnya Agama Islam yang merupakan Agama mayoritas yang dipeluk masyarakat Indonesia. Nilai agama itulah yang kemudian dijadikan alat politik untuk menyerang pihak Capres Jokowi dari sisi keagamaannya. Satusatunya cara untuk menjadikan strategi populisme ini efektif adalah mendoktrinasi atau mengkampanyekan kepada masyarakat tentang kelemahan-kelemahan Capres Jokowi dalam konteks Agama Islam. Apalagi, tentunya pihak Paslon Nomor 2 mengingat bahwa isu sentimen keagamaan terbukti efektif sebagai salah satu faktor penentu kekalahan Calon Gubernur DKI Jakarta Basuki Tjahja Purnama dan Calon Wakil Gubernur DKI Jakarta, ketika berhadapan dengan pesaingnya, yaitu Calon Gubernur DKI Jakarta Anies 
Baswedan dan Calon Gubernur DKI Jakarta Sandiaga Uno. Tentunya kemenangan dengan menggunakan politik identitas pada peristiwa tersebut dijadikan pembelajaran bagi pertarungan politik pada Pilpres 2019, yaitu dengan dicobanya kembali strategi politik identitas yang dikombinasikan dengan strategi populisme politik untuk menyerang pihak Paslon Nomor 1, yang mana tingkat elektabilitasnya selalu berada di atas tingkat elektabilitas Paslon Nomor 2.

Cara populisme dengan menggunakan politik identitas yang berbasis agama sangat berbahaya dIpraktekkan di Indonesia. Perpecahan di kalangan masyarakat Indonesia, terutama antar umat beragama menjadi rawan terjadi. Ini terbukti pada dinamika di media-media sosial terutama Facebook yang penuh dengan "perang opini" dan bahkan "perang makian" terkait isuisu agama dalam masa kampanye Pilpres 2019. Tidak hanya di kalangan antar umat agama, bahkan di dalam agama itu sendiri secara internal terjadi benturan pandangan yang banyak diantaranya cenderung menjadi sangat ekstrim, misalnya terjadinya fenomena pemberian label 'kafir' bagi kaum seagama yang tidak mendukung Capres/ Cawapres pilihannya. Fenomena bahaya perpecahan ini memang menjadi ciri khas bahaya dari penerapan populisme dengan politik identitas, karena sebagaimana hasil penelitian berbagai pakar di dunia internasional, bahwa populisme yang dilakukan dengan mengandalkan politik identitas sangat cepat pertumbuhannya dalam situasi atau kondisi suatu negara yang sifatnya multikultural dan multietnis, bahkan dalam kasus di Indonesia, adalah multi-agama dan multi-keyakinan.

Sebetulnya bahaya ini dapat diupayakan dicegah pada Pilpres 2019 dengan bercermin dengan apa yang terjadi pada Pilgub DKI Jakarta pada tahun 2017. Banyak kalangan dalam suatu agama mengkafirkan rekan seagamanya yang tidak mendukung Cagub Anies Baswedan. Lebih jauh lagi, bahkan dalam kasus Pilgub DKI tersebut, politik identitas dikerucutkan secara ekstrim menjadi kriteria antara 'pahala' dan 'dosa'. Di berbagai masjid di Jakarta, khutbah Jum'at seringkali dipakai sebagai alat menyampaikan propaganda bahwa memilih pemimpin yang "kafir" adalah suatu dosa besar, dan itu diperkuat dengan dalil atau dasar hukum agama. Sebaliknya, beberapa kalangan pegiat kampanye di lapangan, yaitu yang mendukung Cagub Anies Baswedan (Pasangan Anies-Sandiaga), dengan gencar mengkampanyekan bahwa memilih pemimpin yang seiman atau seagama akan memperoleh pahala Surga. Dikotomi SurgaNeraka, Beriman-Kafir, atau semacamnya seperti itu jelas sangat beresiko memecah persaudaraan, pertemanan, dan bahkan hubungan keluarga di masyarakat Indonesia. Sayangnya, hal ini dipraktekkan kembali dalam Pilpres 2019, meskipun tidak sebesar fenomena pada masa Pilgub DKI Jakarta 2017, dimana faktor politik identitas yang berbasis agama lebih dipertajam dengan politisasi ucapan Cagub DKI Jakarta Basuki Tjahya Purnama (Ahok) yang sempat menyinggung penggunaan Surat $\mathrm{Al}$ Maaidah dalam Kitab Suci al-Qur'an yang dikatakan oleh Ahok banyak dipolitisir oleh politisi dalam berkampanye. Peristiwa ini menimbulkan reaksi keras dari sebagian kalangan umat Islam di Indonesia.

Di dalam Pilpres 2019, dikotomi populisme politik identitas pada masa kampanye yang dipraktekkan adalah kategorisasi antara 'antek asing' vis a vis 'nasionalis', 'komunisme' vis a vis 'agama', dan 'penipu rakyat' vis a vis 'pejuang bagi rakyat'. Pihak Paslon Nomor 2, khususnya Tim Pemenangan Prabowo-Sandi, senantiasa mempropagandakan bahwa pertama, Capres 
Jokowi adalah antek asing Prabowo-Sandi adalah Capres/Cawapres yang nasionalis. Kedua, Capres Jokowi adalah keturunan keluarga simpatisan atau anggota Partai Komunis Indonesia (PKI), dan dalam berpolitik memiliki ideologi komunisme, sehingga itu bertentangan dengan Pancasila, sementara Capres/Cawapres Prabowo-Sandi adalah orang-orang yang taat beragama dan anti komunisme. Ketiga, Capres Jokowi dikategorikan sebagai 'penipu rakyat', sementara Capres/Cawapres PrabowoSandi adalah orang-orang yang senantiasa berjuang bagi rakyat dan siap mengabdi kepada masyarakat dengan tulus.

Jenis populisme yang dilakukan Paslon Nomor 2 sulit didefinisikan masuk ke kategori populisme berdasarkan konsep Canovan, dimana antara populisme wong cilik, populisme otoriter, dan populisme revolusioner tampak memiliki unsur yang terpenuhi dalam strategi politik Paslon Nomor 2. Dengan kata lain, populisme Paslon Nomor 2 tidak bisa dikatakan hanya masuk salah satu kategori populisme saja. Untuk dikatakan masuk ke populisme wong cilik, memang unsur ini pasti ada dalam setiap kampanye, tetapi tidak dominan karena Paslon Nomor 2 juga terlihat melibatkan unsur populisme revolusioner, yang terutama dilakukan dengan penguatan strategi kampanye dengan jargon "2019 Ganti Presiden”.

Perlu dipahami bahwa kata "revolusioner" itu tidak selalu memiliki pengertian yang negatif. Demikian pula populisme revolusioner yang dilakukan Paslon Nomor 2. Kata "revolusi" itu sendiri adalah perubahan secara cepat dan radikal, yang merupakan lawan kata dari "evolusi", yang berarti perubahan secara bertahap dan melalui proses yang tidak serta merta atau tidak cepat atau tidak mendadak. Yang dikehendaki Paslon Nomor 2 adalah murni revolusi dalam arti perubahan yang cepat dan radikal, tetapi masih dalam kerangka mengikuti alur hukum yang berlaku. Yang berbahaya dari populisme revolusioner Paslon Nomor 2 adalah hal itu dijadikan alat oleh pihak-pihak yang tidak bertanggung jawab, yang memanfaatkan spirit revolusioner Paslon Nomor 2 menjadi alat untuk melakukan hal-hal yang terindikasi merupakan makar terhadap Pemerintah yang sah. Indikasi makar ini sudah diberlakukan kepada beberapa tokoh yang merupakan pendukung Paslon Nomor 2, yaitu Eggy Sudjana dan Mayor Jenderal (Purn) Kivlan Zen. Penetapan indikasi ini memang kontroversial, tetapi dengan berpatokan pada prosedur hukum yang berlaku, maka bagaimanapun, kedua tokoh tersebut terindikasi melakukan hal-hal yang memenuhi unsur makar. Bahayanya adalah ketika apa yang dilakukan kedua tokoh tersebut menjadi acuan gerakan politik “2019 Ganti Presiden” tersebut. Dalam konteks ini, proses demokrasi yaitu Pilpres 2019 hasilnya selalu diragukan dan selalu disikapi dengan skeptis bahwa kecurangan dari Paslon Nomor 1 mendominasi proses perhitungan suara Pilpres 2019. Sebetulnya itu tidak salah, tetapi ketika dalam proses hukum - dalam hal ini di forum Mahkamah Konstitusi (MK) - pihak Paslon Nomor 2 tidak dapat menunjukkan bukti-bukti yang otentik dan sesuai dengan standar bukti yang diberlakukan berdasarkan peraturan perundang-undangan, maka apa yang dilakukan pihak Paslon Nomor 2 semakin bisa dimasukkan ke dalam unsur populisme revolusioner. Sekali lagi, populisme revolusioner itu tidak selalu bermakna negatif, tetapi dalam kasus Pilpres 2019, maka populisme revolusioner yang digabungkan dengan indikasi adanya upaya makar oleh oknum-oknum pendukung Paslon Nomor 2, maka hal itu akan menjadi 
berbahaya karena diperkuat dengan strategi penggalangan massa atau people power. Sebetulnya menggalang massa atau people power itu adalah keniscayaan dalam suatu persaingan politik untuk meraih kemenangan pemilu, tetapi dalam kasus populisme revolusioner yang terganggu dengan isu makar dalam Pilpres 2019 tersebut membuat populisme revolusioner itu menjadi berbahaya.

Selanjutnya, yang perlu dilihat juga apakah pihak Paslon Nomor 2 melakukan populisme otoriter atau tidak. Dapat dilihat, sebetulnya secara personal, Capres Prabowo Subianto tidak bisa dinyatakan bahwa Capres Prabowo Subianto otoriter, walaupun beberapa kalangan menganggap bahwa dari sisi gerak tubuh, nada bicara, dan sikap-sikap Capres Prabowo Subianto dalam beberapa momen dianggap menunjukkan sisi-sisi otoriter secara pengamatan psikologis. Namun, hal itu tidak bisa dijadikan kesimpulan dari sudut kepemimpinan politik, karena Capres Prabowo Subianto mendapatkan dukungan bukan berdasarkan otoritarianisme dalam kepemimpinannya, melainkan dari faktorfaktor lain yang terbukti mampu menggalang massa dalam jumlah besar secara sukarela. Sisi populisme otoriter justru sedikit-banyak tampak dari fenomena-fenomena dinamika kampanye dan dukungan yang dilakukan berbagai kalangan dan juga oknum-oknum yang sebagaimana disinggung sebelumnya, melakukan kampanye dengan pandanganpandangan politik yang otoriter, yaitu dalam arti memberikan batas pemisah yang tajam antara pihak pendukung Paslon Nomor 1 dengan pendukung Paslon Nomor 2.

\section{Populisme yang dilakukan Paslon Nomor 1 (Jokowi-Ma'ruf)}

Populisme dengan basis strategi politik identitas juga dilakukan oleh Paslon Nomor
1. Perbedaannya dengan populisme yang dilakukan Paslon Nomor 2 adalah bahwa yang dilakukan Paslon Nomor 1 lebih bersifat counter attack atas serangan politik berbasis pendekatan agama kepada Capres Jokowi, khususnya. Keputusan Capres Jokowi memilih K.H.Ma'rufAmin sebagai Cawapres merupakan langkah politik pertahanan untuk mempersiapkan diri menghadapi serangan politik yang berbasis isu agama. Tampak bahwa Capres Jokowi belajar dari pengalaman yang dialami oleh Cagub DKI Jakarta Ahok ketika dikalahkan oleh Cagub Anies Baswedan, yang sebagian metodenya adalah dikalahkan dengan menggunakan isu agama. Dengan mengambil K.H. Ma'ruf Amin sebagai Cawapres, diharapkan tentunya bisa merepresentasikan sebagian masyarakat Islam dapat melihat bahwa Capres Jokowi tidak anti Islam, tidak mengalami "Islamophobia", sebagaimana yang sering dipropagandakan oleh pihak pendukung Paslon Nomor 2.

Strategi politik identitas memang mau tidak mau perlu dilakukan oleh Paslon Nomor 1 agar pemberitaan terkait pendiskreditan dalam konteks "tidak Islami" pada Paslon Nomor 1 tidak menjadi suatu pelemparan isu yang pada akhirnya akan menjadi kepercayaan atau keyakinan publik. Perbedaannya, Paslon Nomor 1 tidak melakukan politik identitas sebagai center kekuatan dan pergerakan kampanyenya. Hal ini terbukti dengan tidak melakukan doktrinasi bahwa pendukung Paslon Nomor 2 adalah kaum yang salah secara agama, misalnya dengan memberikan label kata "kafir" bagi pendukung Paslon Nomor 2. Berbeda dengan itu, di media sosial, terutama Facebook, banyak ucapanucapan dari oknum pendukung Paslon 2 yang melabeli pendukung Paslon Nomor 1 sebagai kelompok yang "tidak Islami", "kafir", atau sebutan-sebutan lainnya yang 
memberi kesan bahwa dengan mendukung Paslon Nomor 1, maka itu adalah suatu dosa atau menyalahi aturan agama.

Populisme politik identitas yang bersifat kesukuan tidak menjadi andalan Paslon Nomor 1. Meskipun Capres Jokowi menang di Provinsi Jawa Tengah dan Jawa Timur, yang mana banyak kalangan hal itu dikarenakan faktor sentimen kesukuan, yaitu Suku Jawa, dalam setiap kampanye Paslon Nomor 1, tidak terasa orientasi politik pada strategi menggunakan populisme secara kesukuan. Sekali lagi, populisme yang dilakukan Paslon Nomor 1 adalah lebih pada strategi defensif yang dalam konsep politik digunakan ketika lawan politik menggunakan strategi menyerang (ofensif). Dalam Pilpres 2019, Paslon Nomor 2 menyerang dengan menggunakan populisme politik identitas agama, maka Paslon Nomor 1 melakukan strategi defensif dengan melakukan hal yang sama.

Selanjutnya, populisme Paslon Nomor 1 tampak menekankan pada orientasi politik pesaing, dimana kelemahan Paslon Nomor 2 diungkapkan dalam kampanye, sebagai counter atas serangan Paslon Nomor 2 yang mengarah pada kelemahan-kelemahan pelaksanaan pemerintah oleh Presiden Jokowi, khususnya dalam hal perekonomian. Dalam konsep strategi politik, memang strategi politik yang berorientasi pesaing perlu dihadapi dengan cara yang sama, yaitu dengan berorientasi pesaing pula.

\section{Populisme pada Pilpres 2019: Politik Identitas yang "Kebablasan"}

Dari uraian di atas dapat kita lihat bahwa baik Paslon Nomor 1 maupun Paslon Nomor 2 sama-sama menggunakan politik identitas. Namun, dalam hal populisme, Paslon Nomor 2 lebih memiliki strategi orientasi politik yang terfokus. Sebetulnya, populisme yang didasari oleh politik identitas adalah wajar dalam memperjuangkan kemenangan dalam suatu persaingan politik, khususnya pada momen pemilu. Hal itu adalah bagian dari strategi politik pemenangan pemilu dengan orientasi politik pesaing. Dalam strategi orientasi politik pesaing, kandidat pemilu harus terus-menerus memonitor pesaingnya, khususnya dalam mengambil langkah menarik perhatian masyarakat. Sebagaimana yang dinyatakan dalam konsep strategi orientasi politik, faktor budaya seperti agama, sosial, dan latar belakang sejarah, bentuk komunikasi tertentu, dan semacamnya, harus diperhitungkan dalam penyusunan strategi pemenangan pemilu. Populisme yang didasari oleh politik identitas adalah bagian dari strategi tersebut. Apalagi dalam konsep politik disebutkan bahwa faktor-faktor yang ada sebagai unsur pemenangan pemilu seperti kebutuhan, kerangka hukum, atau struktur organisasi, dan lain-lain, pada dasarnya sudah dibentuk oleh pengaruh budaya. Suku, agama, dan ras terkait erat dengan budaya, dan khususnya agama, sangat berkaitan dengan keyakinan masyarakat yang sudah "mendarah daging" dalam kehidupan bermasyarakat. Jadi, memang sudah biasa bila populisme berdasarkan politik identitas dengan orientasi politik pesaing dipraktekkan untuk memenangkan persaingan politik.

Adapun yang menjadi berbahaya adalah manakala populisme dengan politik identitas mengabaikan heterogenitas masyarakat dimana pemilu itu dilaksanakan, dan membuat "jurang pemisah" antar masyarakat. Hal ini sangat berbahaya bila diterapkan di Indonesia yang terdiri dari berbagai macam suku, agama, ras, dan aliran kepercayaan. Bahayanya adalah ketika "jurang pemisah" tersebut didoktrinasikan dalam momen-momen kampanye, sehingga efeknya adalah menimbulkan kebencian 
antar masyarakat yang dukungannya kepada Capres/Cawapres adalah berbeda, dimana hal itu akan mengancam ketertiban dan keamanan dalam kehidupan berbangsa dan bernegara, yang pada akhirnya akan menimbulkan konflik dengan didasari identitas-identitas yang dipolitisasikan dalam strategi pemenangan pemilu.

Dalam Pilpres 2019, dapat diamati bahwa dinamika kampanye politik untuk mendukung Capres/Cawapres menjurus pada penggolongan yang disebut "Cebong" bagi pendukung Paslon Nomor 1, dan sebutan "Kampret" bagi pendukung Paslon Nomor 2. "Pertarungan" opini antar para pendukung masing-masing Paslon hampir selalu didasari oleh penggolongan "Cebong" dan "Kampret" tersebut. Dari berbagai forum kampanye atau forum diskusi terkait Pilpres 2019 di mediamedia sosial khususnya Facebook, dapat dilihat bahwa pembicaraan-pembicaraan yang berkembang tidak jarang mengarah pada saling menghujat, saling menghina, saling melontarkan kata-kata makian yang tidak jarang sangat tidak pantas bagi dipraktekkan bagi kalangan berpendidikan yang mengedepankan etika dan sopansantun dalam berkomunikasi dan berinteraksi dengan orang lain. Hal yang sama juga tampak terjadi pada media sosial Youtube. Dalam banyak video yang terkait Capres/ Cawapres, komentar-komentar dari para Netizens atas video itu, banyak yang sifatnya mengeluarkan kata-kata kasar, sangat tidak bermoral, dan mengabaikan etika kesopanan dan adat ketimuran yang menjunjung tinggi nilai-nilai kesantunan. Akhirnya, seringkali terjadi pula "pertarungan" kampanye politik yang bersifat "adu mulut" di video Youtube tersebut yang seringkali sudah tidak bersifat substansial namun lebih kepada emosi yang bersifat pertengkaran dan bahkan permusuhan. Tentunya ini sangat berbahaya bagi kondisi keamanan di masyarakat.
Dalam tahap ekstrim, sempat muncul wacana yang didoktrinasikan oknumoknum tertentu bahwa mendukung Capres/ Cawapres tertentu adalah haram, atau dicap sebagai kaum munafik atau bahkan kafir. Tentu saja hal ini sangat berbahaya di kalangan internal kaum agama itu sendiri. Dalam hal ini, yang terjadi adalah dalam internal pemeluk Agama Islam di Indonesia. Efek dari kondisi tersebut adalah kondisi kemasyarakatan di Indonesia menjadi rawan untuk "ditunggangi" oleh kepentingan-kepentingan politik tertentu yang membahayakan kedaulatan Negara Kesatuan Republik Indonesia (NKRI). Bagi pihak-pihak yang tidak dapat mengendalikan emosinya, bahkan akan terjebak pada upaya untuk melakukan halhal yang secara hukum positif dinilai sebagai upaya makar terhadap Pemerintah yang sah.

Peristiwa kerusuhan 21-22 Mei 2019 di Jakarta menunjukkan hal itu, dimana berdasarkan investigasi POLRI, ada pihak-pihak yang memanfaatkan situasi penolakan atas hasil Pilpres 2019 untuk mencapai agenda politiknya sendiri, bahkan diberitakan ada upaya pembunuhan terhadap Presiden RI dan beberapa tokoh Pejabat dan tokoh Pengamat/Peneliti Politik di Indonesia. Lebih jauh lagi, ada upaya yang bersifat makar dalam memanfaatkan situasi politik pasca Pilpres 2019.

Peristiwa kerusuhan di Jakarta tersebut ternyata tidak hanya menimbulkan efek sosial di Jakarta itu sendiri. Di Pontianak, dalam waktu yang tidak terlalu berbeda dengan waktu terjadinya kerusuhan 21-22 Mei 2019 di Jakarta, terjadi pula kerusuhan yang serupa, bahkan sempat terjadi kejadian yang mirip di Jakarta, yaitu pembakaran Kantor Polres. Ini menunjukkan indikasi bahwa penunggangan situasi politik pasca Pilpres 2019 sangat berbahaya karena bila tidak ditangani dengan cepat oleh aparat 
keamanan, efeknya akan menyebar ke luar Jakarta, dan bahkan dikhawatirkan akan bersifat nasional.

Memang, kejadian-kejadian pasca Pilpres 2019 yang bersifat menolak hasil Pilpres 2019 dipandang secara kontroversial oleh berbagai kalangan. Pihak yang mendukung Paslon Nomor 1 cenderung membenarkan apa yang sudah dilakukan POLRI dalam peristiwa kerusuhan 21-22 Mei 2019 itu. Di pihak pendukung Paslon Nomor 2, cenderung mengatakan bahwa tindakan POLRI dalam menertibkan dan mengamankan kerusuhan tersebut adalah berlebihan dan cenderung dipolitisir. Namun, lepasdaridua pandangan yang saling bertolak belakang tersebut, bagaimanapun, masyarakat Indonesia menjadi terbelah dengan terlalu tajam menjadi dua pihak yang mana masing-masing pihak menganggap pihak lainnya adalah semacam lawan yang dibenci. Ini sangat berbahaya pada persatuan dan kesatuan bangsa karena didasari oleh populisme dengan politik identitas yang "kebablasan". Disebut "kebablasan" karena menganggap bahwa pihak yang tidak sama identitasnya dengan pihaknya akan dianggap sebagai pihak yang "berdosa". Pihak yang secara ajaran agama tidak dibenarkan. Akibatnya, perpecahan tidak terjadi antar umat beragama saja, melainkan juga di dalam internal penganut agama sendiri. Sebagai negara yang penganut Islam nya adalah mayoritas, hal itu tentunya akan berakibat pada pelemahan Islam itu sendiri di Indonesia. Penganut Islam tidak bersatu lagi, dan hal itu akan dapat dimanfaatkan oleh pihak-pihak yang ingin merongrong kedaulatan NKRI untuk semakin melemahkan persatuan umat Islam dengan sistem politik adu domba ala penjajah Belanda dahulu.

Kondisi tersebut semakin rawan ketika kemajuan teknologi komunikasi dan informasitidakdibarengidengankedewasaan masyarakat Indonesia dalam menggunakan media sosial pada Pilpres 2019. Bahkan, beberapa kalangan menilai bahwa sebagian masyarakat Indonesia lebih tertarik untuk berinteraksi pada berita-berita yang sifatnya belum jelas kebenarannya, atau dengan kata lain adalah hoax, karena sifat beritanya yang cenderung lebih menarik untuk dibicarakan, digosipkan, diperdebatkan, atau bahkan dipertengkarkan, khususnya di forum media sosial, terutama Facebook. Oleh sebab itu, pihak Facebook sendiri sempat memblokir atau menon-aktifkan beberapa akun yang sifatnya dinilai menyebarkan kebencian dan dipenuhi fitnah atau berita-berita hoax.

\section{Kesimpulan}

Dari uraian di atas dapat diambil beberapa kesimpulan, pertama, populisme pada Pilpres 2019 menjadi berbahaya karena mengabaikan heterogenitas masyarakat dimana pemilu itu dilaksanakan, dan membuat "jurang pemisah" antar masyarakat. Hal tersebut sangat berbahaya bila diterapkan di Indonesia yang terdiri dari berbagai macam suku, agama, ras, dan aliran kepercayaan.

Kedua, populisme pada Pilpres 2019 semakin berbahaya dengan maraknya hoax yang berdasarkan fitnah atau berita-berita yang belum tentu kebenarannya, yang diekspos oleh oknum-oknum pendukung Capres/Cawapres untuk menjatuhkan nama baik Capres/Cawapres di pihak lawan. Dalam populisme yang berdasarkan politik identitas agama, itu tidak hanya berbahaya bagi hubungan antar umat beragama, tetapi juga berbahaya bagi hubungan di dalam kalangan pemeluk agama itu sendiri. Dalam hal ini, yang terjadi adalah dalam internal pemeluk Agama Islam di Indonesia. Efek lanjutannya adalah kondisi kemasyarakatan di Indonesia menjadi rawan untuk "ditunggangi" oleh 
kepentingan-kepentingan politik tertentu yang membahayakan kedaulatan Negara Kesatuan Republik Indonesia (NKRI). Bagi pihak-pihak yang tidak dapat mengendalikan emosinya, bahkan akan terjebak pada upaya untuk melakukan halhal yang secara hukum positif dinilai sebagai upaya makar terhadap Pemerintah yang sah, yang seringkali mengatasnamakan ajaran agama tertentu.

Ketiga, bahaya populisme dengan politik identitas yang "kebablasan" dalam Pilpres 2019 tersebut semakin tinggi karena didukung oleh teknologi internet dengan memanfaatkan media sosial untuk berkomunikasi yang mana setiap berita, setiap pandangan, setiap informasi akan sangatcepattersebar,dankeempat, kemajuan teknologi komunikasi dan informasi tersebut semakin rawan ketika kemajuan teknologi komunikasi dan informasi tidak dibarengi dengan kedewasaan masyarakat Indonesia dalam menggunakan media sosial pada Pilpres 2019.

Treatment selanjutnya adalah Pemerintah dan Lembaga Perwakilan Rakyat (DPR RI dan DPD RI) perlu mengajak semua tokoh masyarakat, baik tokoh politik atau tokoh agama, agar mereka semua harus bersama-sama memberikan contoh yang baik, menyadarkan, membangun kembali persatuan berdasarkan kesadaran berbangsa dan bernegara yang berdasarkan Pancasila dan prinsip Bhinneka Tunggal Ika.

\section{DAFTAR PUSTAKA}

Akbar Putra, Rizki. "Pengamat Pasca Pemilu: Pendidikan Demokrasi Penting untuk Membangun Persatuan; Wawancara dengan Pengamat Politik, Direktur Eksekutif Indonesian Public Institute (IPI) oleh Jurnalis Deutsche Welle, Rizki Akbar Putra," 28 Juni 2019, diakses 27 Juli 2019. https://www.dw.com/id/ pengamat-pasca-pemilu-pendidikandemokrasi-penting-untuk-membangunpersatuan.

Ar-rasyid, Harun. "Populisme, Politik Identitas dan Pemilu 2019," detiknews, 11 Mei 2019, diakses 2 Juli 2019. https:// news.detik.com/kolom/d-4545249/ populisme-politik-identitas-danpemilu-2019.

Basuki, Dian. "Pamor Pileg Tenggelam oleh Pilpres," Indonesiana, 27 April 2019, diakses 3 Juli 2019. https://www. indonesiana.id/read/130137/pamorpileg-tenggelam-oleh-pilpres.

Canovan, Margaret. ed. Yves Me'ny. Democracies and the populist challenge. Basingstoke: Palgrave, 2002.

Fukuyama, Francis. Against Identity Politics. New York: Foreign Affairs, 2018.

Hefner, Robert W. Politik Multikulturalisme: Menggugat Realitas Kebangsaan. Yogyakarta: Impulse, 2007.

Heller, Agnes dan Sonja Puntscher Riekmann. Biopolitics: The Politics of The Body, Race and Nature. Brookfield: Avebury, 1996.

Kellas, James G. The Politics of Nationalism and Ethnicity, Edisi II. New York: ST Martin's Press, 1988.

Kyle, Jordan dan Limor Gultchin. Populists in Power Around the World. London: Tony Blair Institute, 1997. 
Laclau, Ernesto. On Populist Reason. London: Verso, 2005.

Melendez dan Cristobal. "Political Identities: The Missing Link in The Study of Populism," Journal Party Politics Volume 25 (July 2017). Chile: Diego Portales University.

Moffit, Benjamin. The Global Rise of Populism: Performance, Political Style and Representation. Redwood City: Stanford University Press, 2016.

Mudde, Cas. The Populist Zeitgeist. Government and Opposition. Cambridge: Cambridge University Press, 2004.

Müller, Jan-Werner. Parsing populism. Who is and who is not a populist these days? New York: Juncture, 2015.

Pelfini, Alejandro. ed. Boike Rehbein. Global and National Political Elites in South America: Limited transnationalization processes and the persistence of inequality In Globalization and Inequality Inemerging Societies. Basingstoke: PalgraveMacMillan, 2015.

Putri, Zunita dan Dwi Andayani. "MK Tolak Gugatan Pilpres PrabowoSandiaga," detiknews, 27 Juni 2019, diakses 6 September 2019. https://news. detik.com/berita/d-4603147/mk-tolakgugatan-pilpres-prabowo-sandiaga.

Ristianto, Christoforus. "Pemaparan Direktur Eksekutif Indikator Politik Indonesia Burhanudin Muhtadi dalam diskusi dengan tema "Populisme Agama dalam Demokrasi Elektoral 2019" di Cikini, Jakarta Pusat," kompas. com, 29 Mei 2019, diakses 29 Mei 2019. https://nasional.kompas.com/ $\mathrm{read} / 2019 / 05 / 29 / 20001181 /$ politikidentitas-dianggap-sebagai-winningtemplate-di-pilpres-2019.
Ristianto, Christoforus. "Pandangan Pengamat politik dari Universitas Islam Negeri Syarif Hidayatullah (UIN) Jakarta, Adi Prayitno," kompas. com, 15 Mei 2019, diakses 31 Juli 2019. https://nasional.kompas.com/ $\mathrm{read} / 2019 / 05 / 13 / 12132811 / k a l a h-t e l a k-$ di-sumbar-prestasi-jokowi-tak-mampululuhkan-politik-identitas. Schedler, Andreas. "Anti Political Establishment Parties.” Journal Party Politics Volume 2. Chile: Diego Portales University, 1996.

Stavrakakis, Yannis, Kioupkiolis, Alexandros, Katsambekis, Giorgos, Nikisianis, Nikos, dan Siomos, Thomas. Contemporary Left-wing Populism in Latin America: Leadership, Horizontalism, and Postdemocracy in Chávez's Venezuela: Latin American Politics and Society. Caracas: Latin American, 2016.

Surahmat. "Review Toru Takahashi (Nikkei Asian Review)," mata-mata politik, $24 \mathrm{Juli}$ 2019, diakses 31 Juli 2019. https://www. matamatapolitik.com/analisis-pidatokemenangan-jokowi-bagaimana-diksiungkap-pesan-politiknya.

Urbinati, Nadia. Political Theory of Populism; Annual Review of Political Science, Vol. 22. New York: Forthcoming, 2019.

Zhacky, Mochamad. "Komisi II DPR Prioritaskan Revisi UU Pemilu di 2020," detiknews, 14 November 2019, diakses 2 Januari 2020. https://news.detik. com/berita/d-4784680/komisi-ii-dprprioritaskan-revisi-uu-pemilu-di-2020. 